\title{
Status Sosial Unsur Penokohan Pada Cerita Pendek "Sang Guru Juki" Karya Ahmad Tohari
}

\author{
Ardhian Nurhadi $^{\text {a,1 }}$ dan Nova Daniar Adriyanti ${ }^{\text {a,2 }}$ \\ ${ }^{a}$ Universitas Sebelas Maret Surakarta, Indonesia \\ ${ }^{1}$ ardhiandels@gmail.com; ${ }^{2}$ novadaniaradr@gmail.com
}

\begin{tabular}{ll}
\hline Article info & A B S T R A C T \\
\hline Article history: & This study aims to examine and determine the function of social \\
Revised : 15-05-2019 & status and role of the behaviour and character of figures in the \\
Accepted: 28-06-2020 & community system. The data source in this study is a short story \\
entitled "Sang Guru Juki" by Ahmad Tohari. The resulting data \\
is in the form of quotes that contain aspects of social values and \\
status in the short stories. Researchers' data collection \\
techniques used the observation and note technique. The results \\
of the short story analysis contain vital social elements and \\
values, especially in the characterization elements. Some of the \\
intrinsic aspects conveyed in the story have a strong comparison \\
in giving the message through the characters, especially the Juki \\
character. The social element developed in the report include \\
moral aspects, ethical aspects, and educational aspects. The Juki \\
character depicted in the story has a profession as a teacher. \\
However, the behaviours and attitudes that are built into the \\
story do not show Juki's character as a teacher who must be \\
emulated by his students. Juki tends to take advantage of their \\
social status and role to fulfil their desires and desires.
\end{tabular}

Keywords:

Ahmad Tohari sociology of literature the characterizations short story

Sang Guru Juki

Penelitian ini bertujuan untuk menelaah dan mengetahui fungsi status sosial dan peran dalam hubungannya dengan perilaku dan watak tokoh dalam sistem masyarakat. Sumber data pada penelitian ini adalah cerpen berjudul Sang Guru Juki karya Ahmad Tohari. Data yang dihasilkan berupa kutipan-kutipan yang memuat aspek-aspek nilai sosial dan status dalam cerpen. Teknik pengumpulan data peneliti menggunakan teknik simak dan catat. Hasil analisis cerpen memuat unsur dan nilai sosial yang kental terutama pada unsur penokohannya. Beberapa unsur intrinsik yang disampaikan dalam cerita memiliki komparasi kuat dalam penyampaian amanat melalui tokoh-tokohnya terutama tokoh Juki. Aspek sosial yang dikembangkan dalam cerita meliputi aspek moral, aspek etika, dan aspek pendidikan. Tokoh Juki digambarkan dalam cerita memiliki profesi sebagai seorang guru. Namun perilaku dan sikap yang dibangun dalam cerita tidak menunjukkan watak Juki sebagai seorang guru yang harus diteladani oleh muridnya. Juki cenderung memanfaatkan status dan peran sosialnya untuk memenuhi nafsu dan keinginannya sendiri.

Copyright @ 2020 Institut Agama Islam Negeri Syekh Nurjati Cirebon. All rights reserved.

\section{PENDAHULUAN}

Karya sastra atau karya fiksi merupakan gambaran imajiner dari seseorang tentang dunia nyata yang dilihatnya sebagai bagian dari pengalaman. Karya sastra biasanya memiliki keterkaitan erat dengan masyarakat atau kehidupan sosial yang 
ada di dalamnya. Selain itu karya sastra pun memiliki peran dalam pendidikan karakter (Setyorini, 2018). Berbagai karya sastra yang mengusung aliran realisme biasanya mengulik seputar kehidupan seorang tokoh dalam hubungannya dengan masyarakat. Lebih lanjut, menurut Nurgiyantoro (2012) karya sastra merupakan karya cipta baru yang menampilkan dunia dalam bangun kata dan bersifat otonom. Karya sastra itu hanya tunduk pada hukumnya sendiri dan tidak mengacu atau sengaja diacukan pada hal-hal di luar struktur karya sastra itu sendiri.

Semi (2012) berpendapat bahwa suatu hal penting yang harus disadari bahwa karya sastra adalah suatu fenomena sosial. Ia terkait dengan penulis, terkait dengan pembaca, dan terkait dengan segi kehidupan manusia yang diungkapkan di dalam karya sastra. Karya sastra sebagai fenomena sosial tidak hanya terletak pada segi penciptaannya saja, tetapi juga pada hakikat karya itu sendiri. Karya sastra secara umum adalah ekspresi dari seorang penulis dalam menuangkan ide dan imajinasi ceritanya. Sementara menurut Puspita et al (2018) karya sastra pada umumnya berisi tentang permasalahan kehidupan manusia.

Permasalahan kehidupan dihasilkan melalui pengalaman yang didapatkan dari luar atau dari dalam kehidupannya. Setiap tokoh dalam sebuah sastra pasti akan mengalami peristiwa-peristiwa sosial dalam dunia imajinatifnya (Basid \& AsSulthoni, 2018). Peristiwa ini kemudian diterjemahkan dalam penggambaran cerita melalui latar, penokohan, dan rangkaian peristiwa. Melalui unsur tersebut, pembaca karya sastra dapat membuat dunia baru melalui cerita dengan sudut pandang yang disajikan tokoh. Hubungan yang terjalin antara unsur yang digunakan dalam pembangunan cerita, memiliki fungsi lain sebagai pembangun realita dalam cerita. Cerita dituliskan sedemikian rupa sehingga menyerupai keadaan yang benar-benar terjadi dan mewakili kenyataan yang berusaha digambarkan penulis melalui karya sastra. Hun \& Hassan (2017) menyatakan bahwa novel adalah refleksi dari apa yang ada dalam kehidupan nyata.

Ikatan erat karya sastra dengan kehidupan nyata biasanya dimunculkan pada unsur intrinsiknya. Kaitan ini kemudian dapat diketahui dari latar belakang pengarang, atau unsur ekstrinsik lainnya. Pengaruh yang ditimbulkan dari latar belakang pengarang pada karya sastranya cenderung menjadikan ekspresi suatu karya sebagai bentuk pengalaman yang diimajinasikan dan disebarluaskan. Sastra mempunyai fungsi sosial atau manfaat yang tidak sepenuhnya bersifat pribadi. Permasalahan studi sastra menyiratkan atau merupakan masalah sosial: masalah tradisi, konvensi, norma, jenis sastra, simbol, mitos (Welleck \& Warren, 2014).

Realita yang diangkat dalam karya sastra kemudian dilukiskan dengan tambahan-tambahan gaya penulisan yang digunakan oleh pengarang. Penambahan ini dimaksudkan untuk menambah nilai estetis suatu karya sastra. Dalam penulisan, gaya dan nada menjadi hal penting dalam suatu karya sastra. Demi mengaburkan realita yang dimunculkan dalam penulisan karya sastra, pemakaian unsur gaya bahasa ini menjadi hal pokok. Maka, dalam bahasa sastra selain untuk mendukung makna, kata-kata sekaligus diseleksi untuk memperoleh efek keindahan sesuai dengan kriteria atau wawasan keindahan yang diyakini oleh pengarang (Nurgiyantoro, 2014).

Unsur penting penokohan menjadi tidak bisa dilepaskan dari karya sastra manapun. Telaah yang dilakukan pada keberadaan tokoh dan pengaruhnya pada rangkaian peristiwa dalam cerita tentu mendukung kualitas cerita yang ada. Selain itu, penokohan menjadi penting karena melalui sudut pandang yang dibangun dalam cerita, penulis dapat menyampaikan informasi dan realitas sosial yang 
berusaha dibuatnya. Seperti pada penelitian yang dilakukan oleh Utami, Boeriswati, \& Zuriyati (2018) memfokuskan peneltian pada aspek-aspek sosial yang berorientasi pada kesamaan gender yang ada dalam budaya patriarki di Indonesia. Pada penelitian tersebut tokoh perempuan menjadi sorotan pada novel Hanauzumi karya Junichi Watanabe yang menganggap di Jepang, ideologi patriarki diterapkan untuk mengatur sistem kemasyarakatan dan dianut dengan sangat kuat oleh semua kalangan masyarakat.

Cerpen karya Ahmad Tohari yang berjudul Sang Guru Juki, merupakan salah satu karya sastra yang mengangkat permasalahan sosial cukup kental dalam ceritanya. Di dalamnya penjabaran tokoh ditunjukan dengan berbagai cara untuk menunjukkan kondisi sosial yang ada. Kajian ini ditujukan dengan mengupas segala aspek sosial yang ditunjukkan dalam perilaku, sifat, dan watak tokoh dalam cerita. Pendapat yang disampaikan oleh Mukti, Andayani, \& Wardhani (2018) memaparkan bukti bahwa permasalahan pendidikan ada pada murid seperti: tawuran antarpelajar, pergaulan bebas, kasus aborsi, dan narkoba. Namun dalam cerpen Sang Guru Juki, kegagalan dan buruknya citra pendidikan dilihat dari sudut pandang lain.

Menurut Puspitasari, Waluyo, \& Wardhani (2017) kajian sosiologi sastra pada dasarnya akan mempelajari tentang kajian yang terdapat dalam masyrakat dan lingkungan sekitarnya. Telaah kajian dilakukan pada kehidupan sosial tokoh yang tidak bisa dilepaskan dari sistem masyarakat yang berlaku. Pada latar waktu yang diambil yakni pada masa penjajahan, status sosial atau peran sosial menjadi hal yang sangat penting. Seorang bisa dihormati dan disegani karena status dan peran sosial yang dimilikinya Lewat penelitian mengenai lembaga-lembaga sosial, agama, ekonomi, politik dan keluarga yang secara bersama-sama membentuk apa yang disebut sebagai struktur sosial, sosiologi dikatakan memperoleh gambaran mengenai cara-cara menyesuaikan dirinya dengan dan ditentukan oleh masyarakat-masyarakat tertentu (Nasution, 2016).

Pengkajian sastra dengan menggunakan pendekatan sosiologi sastralah yang kemudian menempatkan karya sastra sebagai penggambaran sebuah realitas sosial (Satrio, Doyin, \& Suseno, 2014). Keberadaan tokoh Guru Juki yang merupakan seorang guru, namun dalam cerita ini ditunjukkan memiliki sikap dan perilaku yang tidak lazim sebagai seorang guru. Dalam posisi sosialnya di masyarakat, tokoh tersebut lantas menjadi sorotan utama dalam cerita. Ketidakwajaran Juki sebagai seorang guru menjadi sisi lain cerita. Sudut pandang cerita yang dibuat penulis dalam hal ini lebih menyoroti pada pesan moral dan etika yang berusaha dikuatkan.

Pendekatan sosiologi sastra, pendekatan multidisipliner yang mengkaji hubungan antara kondisi kehidupan sosial amsyarakat dengan karya sastra digunakan dalam tulisan dengan focus sosiologi karya yang memiliki keterkaitan dengan sifat dan kondisi sosial masyarakat (Putro, 2015). Kebiasaan atau tradisi yang dimiliki masyarakat terkadang menjadi suatu hal yang bisa disalahi bahkan dilanggar oleh masyarakatnya sendiri. Namun, berkat adanya status dan peran sosial, batasan pelanggaran dalam masyarakat menjadi lebur bahkan hilang sama sekali.

\section{METODE}

Jenis penelitian ini adalah penelitian deskriptif kualitatif. Sumber data pada penelitian ini adalah cerpen yang berjudul Sang Guru Juki karya Ahmad Tohari. 
Data yang dihasilkan berupa kutipan-kutipan yang memuat aspek-aspek sosial dalam cerpen Sang Guru Juki karya Ahmad Tohari. Teknik pengumpulan data peneliti menggunakan teknik simak dan catat. Mahsun (2006) menyatakan bahwa teknik simak adalah cara yang digunakan untuk memperoleh data dengan menyimak penggunaan bahasa, sedangkan teknik catat adalah teknik lanjutan yang dilakukan ketika menerapkan metode simak.

Teknik simak dan catat berarti peneliti sebagai instrumen kunci melakukan penyimakan secara cermat, terarah dan teliti terhadap sumber data primer atau sumber data utama kutipan-kutipan yang memuat aspek-aspek sosial dalam cerpen Sang Guru Juki karya Ahmad Tohari. Teknik analisis data yang digunakan oleh penelitian ini adalah metode padan. Teknik dasar menggunakan teknik dasar pilah unsur penentu atau teknik PUP. Adapun alatnya adalah daya pilah yang bersifat mental yang dimiliki oleh peneliti. Sesuai dengan jenis penentu yang dipilahpilahkan atau dipisah-pisahkan atau dibagi menjadi unsur itu maka daya pilah disebut daya pilah referensial (Sudaryanto, 2015).

Teknik selanjutnya menggunakan dengan daya pilah sebagai pembedapembeda referen, untuk membagi mana yang termasuk kutipan status sosial pada tokoh di cerpen atau tidak. Daya pilah yang bersifat mental yang dimiliki oleh setiap peneliti selalu digunakan. Daya pilah itu dapat dipandang sebagai alat sedangkan penggunaan alat yang bersangkutan dapat dipandang sebagai tekniknya dalam hal ini dapat disebut dengan teknik pilah unsur penentu atau teknik PUP (Sudaryanto, 2015).

\section{HASIL DAN PEMBAHASAN}

\section{Kedudukan Pengarang dalam Cerpen Sang Guru Juki}

Salah satu jenis sosiologi sastra yang bisa ditelaah untuk mengetahui seluk beluk suatu karya adalah sosiologi pengarang. Studi yang dilakukan pada pengarang, analisis sebuah karya sastra akan sampai pada tahap menghubungkan realitas yang dialami pengarang dengan imajinasi yang dimunculkannya. Pengarang dalam menuliskan karya sastra memiliki kekuatan dalam membangun sudut pandang cerita melalui imajinasi yang disusun dalam rangkaian cerita.

Dalam cerpen ini, pengarang berupaya menghidupkan suatu kesan negatif pada seseorang yang memiliki kasta tinggi dalam status sosial masyarakatnya. Keberadaan tokoh Juki yang berprofesi sebagai seorang guru dan sikap loyalnya dalam mengikuti perang. Meski demikian, selama perjalanannya menempuh perang, Juki justru memanfaatkan kesempatan dengan menikahi atau mengawini banyak perempuan yang ditemuinya. Hal ini menjadi sorotan utama yang berusaha dibangun oleh pengarang dalam mengubah stigma baik pada generalisasi guru sebagai sosok yang layak menjadi contoh dan dihormati dalam masyarakat.

Stigma sosial dalam masyarakat sejatinya telah menegaskan bahwa guru adalah seorang figur yang sudah selayaknya menjadi panutan. Seperti dalam pepatah Jawa bahwa guru adalah sosok yang harus digugu lan ditiru. Meski demikian, cerita tersebut justru memutar fakta yang selama ini banyak orang yakini tentang sikap baik dan etika yang dimiliki oleh seorang guru. Juki yang seorang guru justru memiliki hobi kawin dan bergonta-ganti pasangan secara tidak resmi. Hal ini lah yang sebenarnya berusaha diungkapkan oleh pengarang, bahwa seorang yang memiliki status dan peran sosial tinggi dalam masyarakat, belum tentu mampu membatasi diri dalam norma dan nilai yang menjadi pedoman suatu sistem masyarakat. 


\section{Peran dan Status Sosial Tokoh}

Fokus perhatian sosiologi karya sastra adalah pada isi karya sastra, tujuan, serta hal-hal lain yang tersirat dalam karya sastra itu sendiri dan yang berkaitan dengan masalah sosial (Welleck \& Warren, 2014). Suatu karya sastra yang menyajikan paparan cerita dengan tradisi dan sistem sosial yang kuat akan menciptakan permasalahan pelik yang berkaitan dengan banyak tokoh. Dalam hal ini unsur karya sastra sangat penting sebagai suatu objek analisis karya berdasarkan pada realitas sosial masyarakat. Sosiologi karya pun menaruh perhatian pada beberapa aspek dominan dalam karya sastra, salah satunya pada penokohan. Selain itu, sosiologi sastra juga menilisik jauh ke dalam karya sastra itu sendiri, kemudian mencari hubungannya dengan suatu pengalaman yang ditemui dalam kehidupan masyarakat.

Sosiologi sastra menjadi sangat tepat ketika ulasan masalah yang dimunculkan pada alur cerita berkaitan dengan pelanggaran atau penyimpangan pada norma dan nilai yang dibentuk dalam masyarakat. Melalui sosiologi sastra, pembaca dapat menginterpretasikan suatu klimaks dari cerita menjadi refleksi dalam melihat masalah dari kehidupan nyata dalam sudut pandang lain. Pendekatan ini ada kecenderungan melihat hubungan langsung (one-to onecerrespondence) antara unsur karya sastra dengan unsur dalam masyarakat yang digambarkan dalam karya itu (Swingewood dalam Junus, 1986).

Dalam cerpen Sang Guru Juki, permasalahan muncul manakala tokoh Juki yang merupakan seorang guru ini memiliki suatu hal yang istimewa atas peran atau statusnya sebagai guru. Peran dan status sosial yang dimiliki seseorang menjadi salah satu aspek bagaimana seseorang tersebut bisa mengambil suatu bagian dalam sistem masyarakat, begitu pula dengan Juki yang cukup disegani dan dihormati sebagai guru.

Klasifikasi dari peran dan status sosial ini pernah disusun dalam suatu kasta yang berbeda-beda. Namun, kini penghapusan sistem kasta dalam masyarakat membuat peran sosial seharusnya menjadi lebur. Atas dasar persamaan derajat manusia, kedudukan dan status sosial dianggap hanya batas kabur yang sejatinya tidak perlu di indahkan dalam sistem masyarakat. Namun, justru saat ini peran dan status sosial menjadi suatu kebutuhan bagi kalangan masyarakat tertentu. Melalui tokoh Juki, pengarang akan menggiring pembaca untuk melihat sisi lain dari seorang guru yang membutuhkan status sosial untuk mendapatkan atau memenuhi nafsu pribadinya.

Pada masa penjajahan, semua orang menjadi tentara apapun profesinya. Begitu juga dengan Juki yang turut berperang bersama teman-temannya. Pengorbanan yang ia lakukan, sampai meninggalkan anak dan istrinya. Seolaholah pada awal cerita, Juki merupakan gambaran sosok yang nasionalis dan rela berkorban. Gambaran dari pengorbanan yang dilakukannya untuk membela tanah air tak lain dan tak bukan hanya memenuhi status dan kedudukannya sebagai seorang guru yang harus memiliki jiwa nasionalis. Penegasan sikap nasionalisme Juki digambarkan secara jelas pada narasi yang mengarahkan pada tindakannya, dalam kutipan berikut.

Maka istrinya, Rosni, dengan dua anaknya yang masih kecil ditinggalkan pada mertuanya di kota. Karena perempuan tidak perlu ikut perang. Apalagi membawa anak-anak yang masih bayi. Mereka akan jadi beban perang saja, katanya memberi alasan pada istrinya. 
Kutipan di atas menunjukkan kebiasaan yang terbentuk dalam ranah peperangan dan perjuangan dalam mengusir penjajah. Perempuan yang dianggap sebagai kaum lemah, tidak boleh ikut perang meski ada beberapa perempuan yang pergi untuk berperang. Perang hanya boleh dilakukan oleh laki-laki dan apapun profesinya sebagai bagian dari sikap nasionalisme dan cinta pada tanah airnya.

Namun, pengorbanan itu bukanlah menjadi sesuatu yang disoroti dalam permasalahan cerita ini. Masalah utama yang berusaha dibangun dari sudut pandang penulis adalah sikap dan tingkah laku Juki serta bagaimana ia memanfaatkan status sosialnya untuk memuaskan hasratnya. Maka dalam cerita, ketika tinggal di desa dan menetap di rumah muridnya yang bernama Siti, Juki pun melupakan Rosni dan anak-anaknya di kota dan menjalin cinta dengan Siti yang merupakan muridnya. Dikuatkan dengan kutipan berikut.

Sitti, murid yang penuh perhatian mengurus kepentingannya terasa sebagai seorang wanita. Juki tergoda.Sitti dipeluk dan diciumnya. Mulanya pada pipi.Lalu seterusnya pada bibir. Dan kemudian mereka kawin. Maka lupalah Juki pada anak dan istrinya yang di kota.

Kutipan di atas tentu menjadi sebuah penggambaran tidak lazim dari tingkah laku yang dilakukan guru pada muridnya. Siti yang semula menjadi murid yang berusaha berbuat baik dengan memberi tumpangan tempat tinggal pada gurunya, justru malah menjalin cinta terlarang dengan gurunya sendiri. Penyimpangan dari aturan masyarakat pun sebenarnya telah terlihat dalam hal ini. Namun penegasan-penegasan lain dalam cerita selanjutnya lebih menguatkan karakter sosok Juki yang sebenarnya tukang kawin, dan sok bijaksana.

Penyimpangan pada status sosial lebih ditegaskan lagi pada cerita selanjutnya. Ketika desa diserang dan Juki mulai terdesak, pergilah ia mengungsi ke rumah muridnya yang lain bernama Oncon. Oncon yang tinggal bersama ibunya yang telah lama menjanda, memberikan kesempatan pada Juki untuk mengulangi kebiasaannya kawin lagi. Kutipan berikut.

Kata orang, setiap laki-laki yang pernah berulang kawin, tidak sulit mengulangnya berkali-kali. Juki laki-laki yang seperti itu. Apalagi jauh di pedalaman yang tidak diketahui berapa lama lagi dia harus mengungsi. Lewat sebulan tinggal di rumah Ibu Oncon, maka kawin lagilah dia. Kawin dengan perempuan yang sudah lama menjanda, Juki dimanjakan benar.

Kutipan di atas sejatinya menunjukkan suatu tradisi dalam masyarakat yang dipegang oleh masyarakat itu sendiri.Pada kalimat "Kata orang, setiap laki-laki yang pernah berulang kawin, tidak sulit mengulangnya berkali-kali”, merupakan kalimat yang menekankan pada suatu stigma yang dipegang oleh masyarakat. Ketika seorang anggota dalam masyarakat itu melanggar, maka sanksi sosial yang tepat dilayangkan pada pelaku. Namun, karena status sosial yang disandang Juki sebagai seorang guru, maka warga masyarakat pun tidak pernah menaruh curiga pada kebiasaannya yang suka kawin dan selingkuh ini.Selain itu pada kutipan tersebut memberikan gambaran nilai watak tokoh Juki yang pandai memanfaatkan peluang. Pada kalimat "Apalagi jauh di pedalaman yang tidak diketahui berapa lama lagi dia harus mengungsi", terlihat suatu indikasi Juki yang pintar memanfaatkan kesempatan untuk menjalankan kebiasaan buruknya. 
Sikap Juki tentu menyalahi aturan dalam perspektif masyarakat mengenai sosok guru, lebih lagi ditujukan pada dialog yang ada dalam cerita.Juki merasa bahwa status dan kedudukannya sebagai guru lah yang membuat banyak orang desa mau dikawininya atau dinikahinya itu. Hal ini dibuktikan dengan dialognya bersama Dali ketika si Dali memberinya nasihat untuk menghentikan kebiasaan buruknya mengawini perempuan.

"Moralnya? Moralnya adalah pada kebanggaan orang desa dapat suami orang kota seperti aku. Guru lagi."

Kutipan di atas jelas menunjukkan keangkuhan Juki dalam menyandang status sosialnya sebagai seorang guru.Ia menjadi tidak peduli dengan apa yang dikatakan orang dalam masyarakat mengenai moral dan norma sosial. Lebih lanjut, pengaruh status sosial dalam tokoh menjadi permasalahan selanjutnya yang dikembangkan dalam cerita. Saat Dali yang sebenarnya adalah pejuang sejati, dan Juki seorang angkuh yang menyandang status guru, keduanya sama-sama dipenjara. Perbedaan status memberikan pengaruh yang signifikan bagi nasib seseorang di dalam penjara. Hal ini dikuatkan dengan kutipan berikut.

Di penjara itulah Si Dali ketemu Juki lagi. Sekilas saja dia sudah tahu itu temannya. Tapi Juki seperti tidak mengenalnya atau tidak mau mengenalnya lagi. Juki menempati ruangan di samping kantor sipir. Sedangkan Si Dali pada bangsal berbau kencing, yang ditempati oleh lebih dari dua puluh orang, hingga tidurnya berdesakan pada balaibalai besar yang terpasang dari dinding depan ke dinding belakang.

Hal penting dalam kutipan di atas merujuk pada keistimewaan yang didapatkan Juki ketika berada di penjara. Sekilas latar situasi menggambarkan keadaan di dalam penjara yang jauh berbeda. Juki berada atau menempati ruangan di dekat kantor sipir yang tentu saja lebih enak. Sedangkan si Dali menempati bangsal berbau kencing, gambaran dari sebuah latar tempat yang sebenarnya tidak layak huni namun bahkan ditinggali banyak orang dengan berdesak-desakan.

Pada kutipan selanjutnya, penjelasan mengenai perbedaan ruang tahanan tersebut dipaparkan. Perbedaan ruang tahanan bukan berkaitan dengan apa yang dilakukan oleh si tersangka namun lebih pada jenis tahanan. Kutipan berikut menjelaskan.

Dari omong-omong sesama tahanan, di penjara itu ada dua golongan tahanan. Yang mendapat kamar untuk empat tempat tidur sejajar dengan kantor penjara, ialah tahanan politik. Sedangkan yang lain sebagai penjahat perang. Yang tersangka sebagai penjahatan perang, sewaktu-waktu ada yang diambil tengah malam dan tidak pernah kembali. Si Dali tergolong penjahat perang.

Kutipan di atas menegaskan bahwa perbedaan ruang tahanan karena status tersangka yang berbeda.Orang seperti Dali yang merupakan pejuang sejati dalam peperangan, mendapat tempat sangat tidak layak di dalam penjara. Justru orang seperti Juki yang pintar dan memiliki kedudukan sebagai guru, dianggap sebagai tahanan politik yang memiliki tempat lebih enak di dalam penjara.

Selain tokoh Juki, penggambaran perempuan-perempuan dalam cerita ini pun melalui sudut pandang yang tidak biasa. Perempuan mulai dari Rosni, Siti, hingga Baiyyah. Bahkan ketika bertemu dengan Dali di akhir cerita ketika mereka 
sudah sama-sama tua, Juki mengatakan bahwa perempuan terakhir yang dinikahinya adalah seorang Belanda.

\section{SIMPULAN}

Berdasarkan hasil analisis yang telah dilakukan dengan menggunakan teori sosiologi sastra, cerpen berjudul Sang Guru Juki karya Ahmad Tohari memuat unsur dan nilai sosial yang kental terutama pada unsur penokohannya. Beberapa unsur intrinsik yang disampaikan dalam cerita memiliki komparasi kuat dalam penyampaian amanat melalui tokoh-tokohnya terutama tokoh Juki. Aspek sosial yang dikembangkan dalam cerita meliputi aspek moral, aspek etika, dan aspek pendidikan. Tokoh Juki digambarkan dalam cerita memiliki profesi sebagai seorang guru. Namun perilaku dan sikap yang dibangun dalam cerita tidak menunjukkan watak Juki sebagai seorang guru yang harus diteladani oleh muridnya. Juki cenderung memanfaatkan status dan peran sosialnya untuk memenuhi nafsu dan keinginannya sendiri.

Amanat atau pesan moral pun banyak disampaikan melalui aspek penokohan yang dominan. Pesan disampaikan melalui dialog antartokoh dan juga perilaku tokoh pada tokoh lainnya. Seperti kata-kata yang diucapkan oleh Dali, teman Juki yang tulus berjuang melawan penjajah. Meski akhirnya Dali dijebloskan dalam penjara karena menjadi tahanan perang, namun sikap tegasnya dan kebiasaannya yang selalu taat pada tradisi dan norma sosial menjadi amanat tersendiri yang disampaikan penulis dalam cerita tersebut.

Selain itu, aspek pendidikan yang ada dalam cerita menggiring suatu pandangan lain tentang guru. Guru jika dilihat dari kemampuan dalam menyampaikan materi pelajaran dengan baik, belum tentu memiliki nilai moral dan etika yang baik. Cerpen ini mengulik watak dan perilaku seorang guru dari sisi lain. Hal ini menjadi ciri khas penulis yang banyak mengarang cerita pendek dengan sudut pandang luar biasa hingga tidak bisa diprediksi oleh kelompok mayoritas.

\section{DAFTAR PUSTAKA}

Basid, A. \& AsSulthoni, Z. N. R. (2018). Dinamika Ideologi Karman dalam Novel Kubah Karya Ahmad Tohari berdasarkan Perspektif Sosiologi Sastra Marxisme. Jurnal Pendidikan Bahasa dan Sastra, 18(1), 58-68.

Hun, K. Y. \& Hassan, U. H. A. (2017). Dakwah, Wealth and Desire of Sexuality In Islam: The Concept Of Love In Habiburrahman El-Shirazy's Ayat-Ayat Cinta 2. Journal Indonesian Language Education and Literature, 2(2), $106-120$.

Junus, U. (1986). Sosiologi Sastra: Persoalan Teori dan Metode. Kualalumpur: Dewan Bahasa dan Pustaka Kementerian Pelajaran Malaysia.

Mahsun. (2006). Metode Penelitian Bahasa: Tahapan Strategi, Metode, dan Tekniknya. Jakarta: PT Raja Grafindo Persada.

Mukti, W. I., Andayani, \& Wardani, N. E. (2018). Potret Pendidikan Pesantren Dalam Novel Ayat-Ayat Cinta 2. Journal Indonesian Language Education and Literature, 3(2), 181-195.

Nasution, W. (2016). Kajian Sosiologi Sastra Novel Dua Ibu Karya Arswendo Atmowiloto: Suatu Tinjauan Sastra. Metamorfosa, IV(1), 14-27.

Nurgiyantoro, B. (2012). Teori Pengkajian Fiksi. Yogyakarta: Gadjah Mada University Press. 
Nurgiyantoro, B. (2014). Stilistika. Yogyakarta: Gadjah Mada University Press.

Puspita, A. C., Suwandi, S., \& Hastuti, S. (2018). Kritik Sosial dan Nilai Moral dalam Novel Negeri di Ujung Tanduk Karya Tere Liye. Indonesian Language Education and Literature, 4(1), 11-21.

Puspitasari, R. H., Waluyo, H. J., \& Wardhani, N. E. (2017). Kajian Sosiologi Sastra dan Nilai Pendidikan Karakter pada Novel Cantik Itu Luka Karya Eka Kurniawan. Aksara, 2(1), 1-16.

Putro, S. C. (2015). Kritik Sosial dalam Novel The Da Peci Kode Karya Ben Sohip dan Implikasinya terhadap Pembelajaran Bahasa dan Sastra Indonesia. Dialektika: Jurnal Bahasa Sastra dan Pendidikan, Bahasa Sastra Indonesia, 2(1), 77-88.

Satrio, B. S., Doyin, M., \& Suseno. (2014). Kritik Sosial dan Hegemoni Kumpulan Cerpen Emak Ingin Naik Haji Karya Asma Nadia. Jurnal Sastra Indonesia, 3(1), 1-9.

Semi, M. A. (2012). Metode Penelitian Sastra. Bandung: Angkasa.

Setyorini, R. (2018). Karakter Kerja Keras dalam Novel Entrok. Indonesian Language Education and Literature, 3(2), 111-122.

Sudaryanto. (2015). Metode dan Aneka Teknik Analisis Bahasa: Pengantar Penelitian Wahana Kebudayaan Secara Linguistis. Yogyakarta: Duta Wacana University Press.

Utami, R. P., Boeriswati, E., \& Zuriyati. (2018). Hegemoni Patriarki Publik Terhadap Tokoh Perempuan dalam Novel Hanauzumi Karya Junichi Watanabe. Journal Indonesian Language Education and Literature, 4(1), 62-74.

Welleck, R. \& Warren, A. (2014). Teori Kesusastraan. Jakarta: Gramedia. 